\title{
SNX18 Gene
}

National Cancer Institute

\section{Source}

National Cancer Institute. SNX18 Gene. NCI Thesaurus. Code C101744.

This gene is involved in both endocytosis and protein trafficking. 